likely to be found. But the most serviceable features are the precise instructions for collecting worms, free and parasitic, and for anæsthetising and preserving them. The pamphlet, of 22 pages, is sold at the British Museum (Natural History) at $6 d$.

\section{Ultra-Violet Light at British Health Resorts}

Figures of the amount of ultra-violet light enjoyed by thirty-two British health resorts during the summer months, July, August, and September, are given in Sunlight (vol. 2, No. 7, p. 209). St. Ives heads the list with a daily average of $6 \cdot 6$ 'units', and none had less than $1 \cdot 3$ units. Half a unit is sufficient to cause perceptible sunburn.

\section{Spring Lectures at the Royal Institution}

THE session of public afternoon lectures at the Royal Institution was opened by Prof. J. C. McLennan, who is giving an experimental course on the work on "Low Temperatures and Low Temperature Phenomena" with which he and the University of Toronto have been specially identified. A course on "Recent Advances in Genetics" is to be given by Prof. J. B. S. Haldane, who has recently returned from a visit to the laboratories at the University of California and elsewhere in the United States. Later courses are by Sir William Bragg, who will review the progress in the past twenty years of the science of crystal analysis by $\mathrm{X}$-rays; and $\mathrm{Mr}$. A. R. Hinks, secretary of the Royal Geographical Society, on "Geography in the Public Service". Mr. Hinks will speak on the new one inch Ordnance Survey map, and the delimitation of national boundaries. Lord Rutherford will give a Saturday course on the "Detection and Production of Swift Particles". The course will be experimental, and as a part of his subject Lord Rutherford will describe the recent progress at the Cavendish Laboratory by Chadwick, Cockroft and Walton and others. Sir James Jeans will give a course on "Modern Astronomy". The new Fullerian professor of physiology at the Royal Institution, Prof. G. Elliot Smith, will give a course on the "Evolution of the Mind". The session will conclude with a display of films, entitled "Developments in Cinematography". Instructional films, colour films, and films in relation to aeronautical research will be shown.

\section{Announcements}

Aт a meeting of the Harrison Memorial Prize Selection Committee on January 13, the Harrison prize for 1932 was awarded to Dr. H. J. Emelóus, of the Imperial College of Science, London.

Tre Gold Medal of the Royal Astronomical Society has been awarded this year to Dr. V. M. Slipher, director of the Lowell Observatory, for his spectroscopic researches on planets, stars and nebulæ. Dr. Slipher has been invited to deliver the George Darwin Lecture for 1933. At the annual general meeting of the Society on February 10, the president, Dr. H. Knox-Shaw, will deliver an address on "The Distances and Motions of the Extra-Galactic Nebulæ".
Tне following have been appointed to the Safety in Mines Research Board: Dr. C. V. Drysdale, director of Scientific Research at the Admiralty, Mr. F. Edmond, chief mining agent to the Wigan Coal Corporation, Ltd., and Major H. M. Hudspeth, chief mining engineer to the Board. The appointment of Prof. J. F. Thorpe would normally have ended on December 31 last, but Prof. Thorpe has accepted a special extension of his term of service for a period of two years. Prof. C. H. Lees, whose appointment was specially extended at the end of 1931, has now completed his term of service.

DR. R. R. Marett, Rector of Exeter College, Oxford, has been appointed Donnellan lecturer for 1933 in Trinity College, Dublin. The lecture will probably be delivered in the second week in May. An earlier date than usual is being arranged to suit Dr. Marett's other engagements. He has announced the subject of the lecture as "Pre-theological Religion in Feeling, Thought and Action".

A course of four public lectures entitled "An Introduction to Indian Archæology" will be given by Mr. F. J. Richards, honorary lecturer in Indian archæology at University College, London, beginning on Tuesday, January 24, at 5.30 P.M., and thereafter at the same time on each Tuesday until February 14. The subjects of the lectures will be : physical factors; human factors ; religious complexities ; arts, useful and otherwise. The lectures are open and the public will be admitted without fee or ticket.

By arrangement with the Polytechnic, Regent Street, London, and the National Illumination Committee and the Illuminating Engineering Society, a course of ten lectures on illumination will be given at the Polytechnic on Wednesdays beginning February 8 . The lectures will deal with various aspects of illumination and will be delivered by experts in the respective subjects. Further information can be obtained from the Director of Education, The Polytechnic, 309 Regent Street, W.1.

ApPlications are invited for the following appointments, on or before the dates mentioned :--A wholetime abstractor and translator (at Sheffield) for the Safety in Mines Research Board-The UnderSecretary for Mines, Establishment Branch, Cromwell House, Dean Stanley Street, Millbank, London, S.W.1 (Feb. 4). A public and agricultural analyst and gas examiner for the County of Derbyshire-The Clerk to the County Council, County Offices, Derby (Feb. 4). A librarian for the Halesowen Urban District Council-The Clerk, Cornbow House, Halesowen (Feb. 10). A specialist in biochemistry and physiology in relation to food and nutrition on the medical staff of the Ministry of Health-The Director of Establishments, Ministry of Health, Whitehall, S.W. (Feb. 13). A metropolitan meat industry commissioner for the Government of New South WalesThe Minister for Public Works and Health, Department of Public Health, Sydney, Australia (March 31). 